\title{
Cantando el sufrimiento del río. Memoria, poética y acción política de las cantadoras del Medio Atrato chocoano
}

\author{
Singing the River's Suffering: Memory, Poetics and Political Action \\ of the Cantadoras of the Middle Atrato in Chocó
}

\author{
Pilar Riaño-Alcalá* \\ Institute for Gender, Race, Sexuality and Social Justice, University of British Columbia, Canadá \\ Ricardo Chaparro Pacheco* \\ Franciscan University of Steubenville, Estados Unidos
}

DOI: $10.22380 / 2539472 X .793$

\begin{abstract}
RESUMEN
Desde la comunidad de Pogue, un grupo de cantadoras lleva los alabaos a diferentes escenarios públicos, como sucede en las conmemoraciones de la masacre de Bojayá o la firma del acuerdo de paz. Al situar el afecto y el sentimiento como fuerzas creadoras del canto, la composición y la puesta en escena, las cantadoras de Pogue recrean lenguajes y modos de acción política. Con una voz colectiva construyen una narrativa sonora que expresa tanto su dolor como sus reivindicaciones. El sentimiento comunica un conocimiento emocional y encarnado de las mujeres e impulsa formas propias de producción de memoria histórica y acción política. Explorando el canto, el sentimiento y la guerra, este artículo apunta a las intersecciones entre cultura, política y resistencia que representan dichas composiciones y prácticas de cantar.
\end{abstract}

Palabras claves: sentimiento, memoria sonora, reparación social, acción política.

\begin{abstract}
From the community of Pogue, a group of cantadoras sing alabaos in different public scenarios such as the commemorations of the Bojayá Massacre or in the signing of the Peace Agreement. By putting affect and feeling as creative forces of song, composition and performance, the Pogue singers recreate languages and modes of political action. With a collective voice, the singers construct a sound narrative that expresses their pain and their demands. Feeling in this context communicates women's emotional and embodied knowledge, and activates forms of production of historical memory and productive political action. Through the exploration of song, feeling and war, the article examines the intersections between culture, politics and resistance that these compositions and singing practices represent.
\end{abstract}

Keywords: Feeling, sound memory, social repair, political action.

pilar.riano@ubc.ca / https://orcid.org/0000-0002-4757-893X

rchaparropacheco@franciscan.edu / https://orcid.org/0000-0002-1819-1920 
Uno con esa letra, con esa música... Expresando el dolor, el sufrimiento del río. (Cantadora de Pogue, taller, diciembre del 2014)

1 Cómo escuchar los registros sonoros y poéticos que germinan silenciosamente bajo el ruido de la guerra? Sentadas en semicírculo durante una reunión en la comunidad ribereña de Pogue con el grupo de cantadoras de alabaos, Martha ${ }^{1}$, una de las cantadoras mayores ${ }^{2} \mathrm{y}$ quien también es compositora, inicia haciendo "claridad a las cosas": nosotras el 2 de mayo [...] la toma fue el 2 de mayo [del 2002], nosotras desde el 2 de mayo nos nació un sufrimiento, y a través de esos sufrimientos nosotras ya nos fuimos reuniendo en grupo, a hacer composiciones, a sentirle al mundo que nos estaba doliendo, que nos estaban destruyendo, que no nos reparaban, que éramos desplazados luchando y día a día las cosas.

Emiliana, otra cantadora mayor y compositora de Pogue, agrega: desde ese entonces de la toma, iniciamos a componer los cantos de sentimiento, porque como la gente que murieron la mayoría era de acá, familia de uno, porque a mí me cayeron dos primos hermanos con toda su familia [...] de ese dolor tan duro.

Los relatos cantados de los alabaos se caracterizan por su doble constitución: a) son textos poéticos transmitidos por líneas de parentesco y en el ejercicio del canto ritual y del rezo, cuando se acompaña y despide a los muertos por parte de las poblaciones afrocolombianas del Pacífico; y b) son hechos sonoros que se entonan de acuerdo con un esquema melódico rítmico (Tobón 2016; Tobón et al. 2015) y en los que se diferencian los componentes africanos, europeos e indígenas (Valencia 2009). Canto y poesía, y el modo en que se cantan en grupo

1 Los nombres han sido cambiados por seudónimos para mantener la confidencialidad. Las cantadoras de Pogue son reconocidas en Colombia por sus cantos y por sus composiciones que hacen visibles los impactos de la guerra y el sentir de los bojayaseños. Reconocemos y les agradecemos su generosidad y conocimiento. Algunas de sus lideresas son Luz Marina, Ereiza, Oneida, Cira, Eugenia, Máxima. Para conocer más sobre su trabajo y el grupo completo, véanse http://www.icesi.edu.co/vocesderesistencia/lo-mejor-de-nosotras.php, https:// issuu.com/centronacionalmemoriahistorica/docs/pogue-cartilla y Cantadoras de Pogue, Riaño-Alcalá y Chaparro (2016).

2 A partir de las dinámicas del canto del alabao que se explican más adelante, las cantadoras de Pogue distinguen entre las mayores, quienes tienen la suficiente potencia, conocimiento y confianza en su voz para iniciar el alabao, y las respondedoras, quienes repiten en coro el verso de la que inició el canto. 
y “adornados” por el sentimiento ${ }^{3}$, tejen en el Medio Atrato un paisaje sonoro y traen la memoria ancestral, ritual y afectiva para acompañar a los dolientes y una transición sin penas de la vida a la muerte ${ }^{4}$.

La aguda confrontación armada que tuvo lugar en el Medio Atrato entre paramilitares y guerrilleros durante los años 1990 e inicios de los 2000 sometió a la población de esta región y a sus organizaciones a amenazas, asesinatos selectivos de líderes indígenas, negros y religiosos, quemas de poblados, desplazamientos masivos, confinamientos y al asedio armado (Gómez 2012). En este contexto, Bellavista, casco urbano del municipio de Bojayá, fue el escenario de una de las masacres más mortíferas en la historia de la guerra en el país. El 2 de mayo del 2002, cuando "[e]n medio del furor de la batalla entre guerrilleros de las FARC [Fuerzas Armadas Revolucionarias de Colombia], el grupo guerrillero más grande del país, y paramilitares de derecha, un mortero rudimentario disparado por la guerrilla cayó en la iglesia donde los bojayaseños habían buscado refugio” ("Bojayá, un símbolo del dolor que le apostó a la paz y ahora teme el regreso de la guerra” 2016). A pesar de las siete alertas tempranas que la comunidad había hecho al Gobierno sobre el inminente riesgo que corrían, la protección nunca llegó. Murieron aproximadamente cien personas, más de la mitad eran menores de edad, y la comunidad señala con insistencia que varios de sus sobrevivientes han ido falleciendo a causa de las heridas físicas y psicológicas con las que quedaron por aquel hecho (Comité por los Derechos de las Víctimas de Bojayá 2019; GMH-CNRR 2010; Equitas 2018; Orjuela 2017).

Tan pronto cedieron los combates, los sobrevivientes de la masacre huyeron masivamente, enterraron apresuradamente a quienes pudieron en una fosa común y sin poder hacerles los rituales propios con los que los afrochocoanos del Medio Atrato acompañan el tránsito desde el mundo de la vida y de la materialidad corporal hacia el mundo de los muertos. Las violencias, con su estela de muertes súbitas, desapariciones que no dejan rastro y el exilio del territorio y del río, quiebran los mundos sociales y sagrados de los bojayaseños, afectando profundamente sus entornos cotidianos y la relación con sus ancestros.

3 Esta dimensión estética del alabao, y en general de los romances, fue narrada de diversas maneras por las cantadoras y rezanderos de Pogue. José (rezandero y respondedor) lo describe así: "es como una satisfacción para uno, adornar un muerto con esa cantidad de alabaos pesados, como se dice uno, esos alabaos grandes".

4 Los alabaos también son clasificados en una estrecha relación con la forma como la religión católica fue aprehendida en la región. Así, se consideran alabaos mayores los que invocan a la Santísima Trinidad (Dios Padre, Hijo y Espíritu Santo), a la Virgen María o a san Antonio (uno de los santos más venerados en la región, al que se le atribuye un parentesco espiritual con los ancestros africanos). La intercesión de los demás santos es invocada en los alabaos menores (Cantadoras de Pogue, Riaño-Alcalá y Chaparro 2016). 
Como memoria viva de una tradición arraigada, las cantadoras de Pogue son llamadas a cantar cuando los funcionarios gubernamentales y los "internacionales” llegan a la zona. Esto comenzó en noviembre del 2000 con el primer aniversario del asesinato del padre Jorge Luis $\mathrm{Mazo}^{5}$, y después en el 2004, cuando fueron invitadas a cantar en la segunda conmemoración de la masacre, una tragedia por la que aún guardan un profundo duelo como madres, hermanas, abuelas y parientes de muchas de las víctimas que allí perdieron la vida. Así, este grupo de mujeres campesinas, algunas de ellas maestras de escuela rural, con estrechos lazos de parentesco entre ellas y edades que van desde los trece hasta los ochenta años, ha estado presente en cada una de las conmemoraciones, eventos y momentos importantes con funcionarios del Gobierno, presidentes, agencias y delegaciones internacionales que desde ese entonces visitan la región con alguna frecuencia. Las mujeres ven en la invitación a interpretar los alabaos durante estos eventos una oportunidad para subvertir el escenario público y el discurso oficial sobre las víctimas y la guerra, mediante la composición de alabaos que narran y transmiten el "dolor que sentimos". El canto sentido de sus composiciones transforma las conmemoraciones y su representación como "víctimas del conflicto armado" en espacios donde "hablan duro y fuerte” y desde una voz colectiva. Las cantadoras interpelan a los representantes del Estado y las instituciones desde este tejido sonoro de afectos y fuerza acústica, pero en el contexto de una comunicación y relación desigual de poder como mujeres, población negra y sobrevivientes de múltiples formas de violencia.

¿Bajo qué circunstancias el canto tradicional y ritual del alabao se recrea en esta región como una memoria sonora y reparadora del dolor? ¿De qué maneras estos "cantos de sentimiento" se constituyen en registros afectivos mediante los cuales las cantadoras comunican su rechazo a la violencia? Examinamos aquí el modo en que las mujeres cantadoras de Pogue incorporan sentimientos en la composición y puesta en escena de alabaos que cantan el dolor y rechazan la violencia. El artículo rastrea los cambios y movimientos que ocurren cuando la poética del afecto organiza la ética y la política de la memoria y

5 El sacerdote católico Jorge Luis Mazo fue párroco de Bellavista. Los habitantes lo recuerdan por su promoción de organizaciones comunitarias que asumieron la neutralidad activa frente a los actores armados en disputa en la región, y que gestionaron alimentos y ayuda humanitaria en los sucesivos confinamientos armados de los que fue objeto la población. La noche del 18 de noviembre de 1999, el bote en que se movilizaba sobre el río Atrato junto con una comisión de derechos humanos fue estrellado por otro bote motorizado y de mayor tamaño perteneciente a integrantes del bloque paramilitar que operaba en la región. Todos sus ocupantes fueron lanzados fuera de la embarcación. El cuerpo del sacerdote fue hallado dos días después río abajo, junto al cuerpo del español Íñigo Egiluz, quien acompañaba la labor del padre Mazo (GMH-CNRR 2010, 41). Para ampliar, véase "Jorge Luis Mazo-Sacerdote" (2009). 
activa la práctica conmemorativa. Al poner en el centro el afecto y el sentimiento como fuerzas creadoras del canto, la composición y la puesta en escena de este grupo de mujeres, sugerimos las formas en que ellas recrean lenguajes y modos de acción política. El sentimiento en este contexto comunica un conocimiento emocional y encarnado de las mujeres e impulsa formas de producción de memoria histórica propia (Arboleda 2011; Million 2009).

El artículo examina ese sentir cantado con el que se entonan los alabaos en el Medio Atrato chocoano como una forma creativa de acción política productiva (Clarke 2009), y su inscripción en una ecología de prácticas, huellas y seres que transitan por ríos, entre vivos y muertos, por la selva y los poblados, y en los rituales mortuorios y conmemorativos. Al considerar la memoria sonora del alabao desde su ecología, ponemos atención a lo que Isabelle Stengers (2013) describe como una manera de pensar las prácticas (el canto del alabao) en el entorno relacional, material y afectivo en que se hacen y producen. Es decir, nos aproximamos a esta memoria sonora, su identidad y comunicabilidad atentos al entramado de relaciones y materialidades, fuerzas y seres que la rodean, la contextualizan y le dan vida. La identidad del canto del alabao y los momentos en los que se invoca tienen una profunda interdependencia con el entorno acústico y el movimiento del río como vehículo que posibilita y guía el canto, así como con el entorno selvático y húmedo en el que operan mundos de vivos y de muertos (Friedmann 2006). Los modos en que las cantadoras invocan el alabao en el Medio Atrato revela también el entorno de la guerra en la región y las maneras complejas y ambiguas en que el entramado institucional que se construye alrededor de la justicia transicional, la memoria y la paz a partir de la masacre entra en relación y busca apropiar la voz de las cantadoras como víctimas y como mujeres negras.

El artículo se basa en los resultados de uno de los proyectos de investigación en los que trabajamos en el Medio Atrato entre el 2014 y el 2018. El proyecto "El oficio de cantar memoria" 6 examina los trabajos del canto, la composición y la memoria de las cantadoras de Pogue como una iniciativa de memoria oral y sonora de los pueblos afroatrateños en un contexto de conflicto armado. Nuestra vinculación con la región inició en el 2009 cuando fuimos parte del equipo de investigación (correlatora e investigador) para el informe del Grupo de Memoria Histórica Bojayá. La guerra sin límites (GMH-CNRR 2010). Posteriormente, emprendimos el trabajo de investigación de acuerdo con la consulta y

6 Este proyecto fue financiado por el Consejo Canadiense de Investigación en las Ciencias Sociales y Humanas (SSHRC) y un fondo de la Facultad de Artes de la University of British Columbia. 
los requerimientos del grupo de cantadoras, el Consejo Comunitario de Pogue y el Consejo Comunitario Mayor de la Asociación Campesina Integral de Atrato (Cocomacia). Durante el trabajo de campo documentamos los sonidos, las letras y el proceso de composición de los alabaos, la trayectoria del grupo y su oficio de cantar memoria y composiciones mediante entrevistas grupales e individuales, talleres y reuniones con el grupo, en visitas y charlas en sus casas, o cuando las acompañamos a la conmemoración de la masacre o durante la Semana Santa. El análisis y las reflexiones durante el proyecto se enriquecieron con la interlocución con las cantadoras en estos espacios y en tres encuentros que sostuvimos en Pogue y Bellavista para el análisis del material. En este trabajo ${ }^{7}$ también han sido fuente de inspiración y diálogo constante dos líderes y pensadores chocoanos, Leyner Palacios y Delis Palacios; la misionera agustina Auria Saavedra, así como los colegas investigadores en la misma región: Natalia Quiceno, Camila Orjuela, Aurora Vergara, Germán Arango y Constanza Millán.

\section{El alabao, sus paisajes sonoros, estéticos e históricos}

Es como una satisfacción para uno, adornar un muerto con esa cantidad de alabaos pesados, como se dice uno, esos alabaos grandes.

(José, entrevista, abril del 2014)

Eran cantos de voz que narra, de voz que arrulla, de voz que denuncia, de voz que alaba. (Tobón 2016)

Los alabaos retoman el amplio género literario y musical de los romances, expresión poética en la que convergen música, literatura y oralidad: versos octosílabos de rima continua que narran la vida cotidiana y el imaginario de un grupo de personas en un momento histórico particular (Tobón 2016). Históricamente, los romances llegaron a las Américas con los colonizadores españoles y como parte del proyecto colonial del régimen español (Valencia 2009). Estos fueron una pieza importante en el repertorio de enseñanza e imposición del idioma español por

7 Los protocolos éticos de este trabajo se ajustan a los del Comité de Víctimas de Bojayá. Estos esbozan los principios éticos que deben seguir los investigadores en la región en términos de: a) acceso y negociación de agendas; b) modalidades de producción, manejo, control y propiedad de la información, y c) resultados, usos y estrategias de divulgación. 
parte de misiones evangelizadoras de los pueblos indígenas y negros esclavos de la región del Pacífico durante los siglos XVI, XVII y XVIII (Tobón 2016).

A través de varias formas de romances, las poblaciones negras apropiaron y recrearon este género como práctica renaciente de africanía mimetizada. Adriana Maya (1996) utiliza la noción de la permanencia mimetizada de la africanía entre los descendientes de los esclavos africanos en la Nueva Granada para nombrar el complejo entramado de huellas y prácticas expresivas que no comunican de manera explícita sus raíces. Los alabaos operan bajo este registro. Se trata de coplas y versos que en unos casos evocan el sufrimiento de la esclavitud y el trabajo forzado en las minas, y que narran los sentimientos asociados a vivir en el paisaje agreste de la selva tropical de la cuenca del río Pacífico (Tobón 2016).

A Pogue, los romances llegaron a inicios de la década de 1930, prendidos de las voces de Macario Asprilla, de su padrastro, Otaviano Palacios, y de sus hermanas, esposas, hijos, nueras y yernos que los siguieron en un viaje que podía tomar al menos ocho días de navegación por diferentes ríos y los cruces entre estos. Ellos vinieron desde las regiones del Baudó y de Río Quito en el Pacífico colombiano, donde aprendieron a cantar alabaos escuchando y acompañando a sus mayores, quienes a su vez los aprendieron de sus ancestros traídos a la fuerza desde el continente africano y que, esclavizados o ya libertos, "escondieron" en los alabaos acentos y frecuencias musicales y rítmicas en las que la voz se hace tambor, el instrumento prohibido por los colonizadores. Así lo describe Jaime Arocha (2009) para los baudoseños, comunidad de origen de los fundadores de Pogue:

En el caso de los antepasados de los afrobaudoseños, se sabe que fueron víctimas de la persecución de aquellos misioneros que acertaron en ver en el tambor el arma de la libertad (Córdoba 1998). De ahí que lo prohibieran, pero de ahí también que las antepasadas de los afrochocoanos hubieran escondido la rítmica de los cueros dentro de sus voces y que ese lenguaje de la verdad continúen practicándolo con fervor en sus ceremonias fúnebres. En efecto, los alabaos siguen siendo el eje de los rituales mediante los cuales los vivos les reconocen a sus muertos ese estatus que para los occidentales es extraño, el de ancestros vivos. (94)

Estos componentes negros se mezclan creativamente con frecuencias rítmicas y lenguajes que religiosas, misioneros y sacerdotes les imponen en la enseñanza del catolicismo. Con la fundación y dispersión de nuevos poblados negros cada vez más alejados de los pueblos y ciudades que funcionaban como epicentros de evangelización,

las pequeñas comunidades atrateñas fueron dejadas a merced de su propia oralidad y desde ella se hizo posible el nacimiento de una cultura religiosa popular por fuera de la oficialidad católica. Así, construyeron 
particulares espacios en los que se conjugaron las antiguas herencias africanas con el legado sonoro y literario de las narraciones cristianas. (Tobón 2016, 55)

Los alabaos se invocan en los momentos de duelo, velorio y entierro de adultos y niños (en este caso, se cantan gualís ${ }^{8}$ ). Recrean prácticas arcaicas populares católicas y el lenguaje de la colonización española de la región ${ }^{9}$, repertorios espirituales africanos (en este caso bantú) que llegaron con los esclavos traídos a la región para trabajar en las plantaciones de banano y en la minería. Su lógica conceptual - las nociones que fundamenta, como la de fuerza vital y la interdependencia entre alma, energía y cuerpo cuando se acerca la muerte- está apoyada en lógicas chamánicas de los grupos indígenas emberas que ancestralmente han habitado este territorio y con quienes han mantenido complejas relaciones e intercambios (Losonczy 1991; Tobón 2016) ${ }^{10}$. El canto del alabao interviene en el campo de las fuerzas vitales y el movimiento que abarca mundos de la vida y de la muerte. Su canto y ritual en el momento crucial de la muerte son parte de los deberes morales de los vivos para facilitar el camino en paz hacia la muerte y para restaurar el balance espiritual y social de la pérdida de una persona.

Las formas musicales del alabao pertenecen al amplio repertorio de música y poética del Pacífico colombiano que, como lo describe Valencia (2009), “están determinadas por células rítmicas con particulares acentuaciones, pulsos, claves,

Como nos lo explicaron las cantadoras y rezanderos de Pogue, "las almas de los niños y las niñas pequeños conservan la inocencia que se pierde en la adultez. Por eso a la velación de un niño muerto o una niña muerta se le llama gualí, en el que se cantan romances y chigualos, un tipo de canto especial cuyos versos y tonadas mantienen un carácter juguetón, pero que no dejan de crear sentimiento de solidaridad en el dolor por la pérdida que su muerte representa" (Cantadoras de Pogue, Riaño-Alcalá y Chaparro 2016, 8).

Como lo notan varias investigaciones (Cantadoras de Pogue, Riaño-Alcalá y Chaparro 2016; Tobón 2016; Tobón et al. 2015), los alabaos conservan arcaísmos poéticos y palabras arcaicas ("esgarra" por desgarra, "senté" por sentí), así como modos de pronunciación que se remontan a la lengua escrita y hablada en los siglos XVI y XVII. Carmen, una cantadora joven y de voz potente, comentó durante una sesión en la que revisamos los temas centrales de la investigación (2014): "y entre otras cosas también mire lo de los alabaos, como es algo tradicional, algo que viene desde los abuelos de nosotros, tampoco no hay como la necesidad de pulir tanto las palabras, porque es sabido pues que en su tiempo ellos de pronto el español no estaba tan acomodado, entonces allí... cuando no, de pronto no... si no que, entonces si nosotros tratamos de pulir las palabras como está el español hoy día, el alabao no nos sale bien, pierde su fuerza y entonces ya no vendría siendo tradición. Porque, o sea, por ejemplo: balcones y en el alabao barcones, palabras como esas". coano, por ejemplo la de fuerza vital y la presencia en el cuerpo de una energía divina que se extingue con el último aliento, como reinterpretaciones de la lógica conceptual del chamanismo embera. 
trastoques, entre otras. Estas características propias surgen a partir de una amalgama sonora tras el encuentro de la cultura afro, indígena y europea” (29).

Si bien la gran mayoría de las cantadoras en el Pacífico colombiano son mujeres, hay también hombres cantadores, como puede concluirse de la misma historia del alabao en Pogue. Cuando en abril del 2014 nos sentamos con Esther, una de las cantadoras mayores del grupo, bajo un árbol al frente de su casa en Pogue, ella nos explicó que "el canto es una rogativa que le hacen al muerto". Esta rogativa es la que permitirá que su alma-fuerza vital ejecute sus últimos pasos en vida, se aleje del cuerpo y pueda pasar al otro lado (Losonczy 1991). Por eso los alabaos no se cantan a cualquier hora, sino cuando hay un difunto en la comunidad y en tres momentos: 1) la noche de la velación, 2) durante su sepelio y 3) en "la última” de las nueve noches que le siguen a la velación y durante las cuales se han celebrado otros rezos y oraciones que marcan, tanto para el alma del difunto como para la comunidad, esa transición de la vida a la muerte. Un cuarto momento para la interpretación de alabaos es la noche del Viernes Santo.

A diferencia de las composiciones en las que nos concentraremos más adelante, las letras de estos alabaos hacen parte del repertorio de oralidad que es transmitido por líneas familiares. Así, las cantadoras fueron aprendiendo su oficio desde niñas, acompañando a sus abuelas, madres, padres y tías a los velorios y escuchándolos cantar alabaos, cantos que luego repitieron en sus propios juegos de levantar tumba (como le llaman los afrochocoanos al ritual fúnebre), y que también aprendieron porque sus mayores las motivaron a no dejar morir la tradición con ellos: “japrendan, que yo no soy semilla!” (Julianita, taller 1, 2014). Nadie se atreve a decir que trae un alabao nuevo si no puede dar cuenta de su inscripción en la tradición de su propia comunidad o de la de otra adonde haya ido a acompañar un velorio y haya convencido a alguna cantadora local de enseñárselo, generalmente a cambio de la letra de un alabao propio que la otra no conozca.

La otra fuente de integración de nuevos alabaos en el repertorio del ritual fúnebre proviene de las personas de entendimiento fuerte, es decir, de aquellas que aprenden su conocimiento, fuerza para invocar alabaos y los nuevos cantos durante el sueño y por una conexión especial con las ánimas, es decir, las almas de los fieles difuntos. Este es el caso excepcional de Petrona, una alabaora mayor con una potente voz y una de las trayectorias más largas y reconocidas en el Medio Atrato, quien ha aportado al repertorio del grupo de Pogue tres alabaos que, en sus palabras, se los enseñaron en sueños las ánimas. Estas revelaciones le han pasado en diferentes momentos de su vida. Durante una entrevista en su casa en el 2013, esto fue lo que nos contó:

Yo estaba durmiendo y mi marido me estaba cuidando porque tenía fiebre... De pronto veo una señora que va y me dice: "Petrona, vos sos 
cantadora. ¿Qué buscás acá? [...] Yo te voy a enseñar un alabao. Yo te lo voy a enseñar porque sos cantadora, para que cuando se muera un moribundo se lo cantés”, me dijo la señora, y ahí verdad me inició ella el alabao.

Esta tradición en la enseñanza y transmisión de los alabaos así como la asignación tan concreta de los momentos en que se cantan dan una idea del tono triste y melancólico que los caracteriza, del tejido afectivo en el que se cantan e interpretan, porque, como nos dijo otra cantadora: "los alabaos dan con ánimo, es lo que conmueve a la gente”, pero también imponen un aura de respeto y se les atribuye poder y fuerza. De esta manera, el alabao hace parte del repertorio de oralidad y memoria sonora en que el canto y la voz "aparece[n] simultáneamente como fuerza que constituye el mundo y medio para construir el conocimiento acerca de este" (Ochoa 2014, 3). El poder afectivo del alabao es una de las vetas desde las que examinamos el papel crucial que estas frecuencias sonoras y prácticas del canto tienen como fuerzas reparadoras de los mundos afectados por la violencia y la pérdida, y también como medio de expresión de su capacidad de agencia para movilizar el quehacer político en el día a día.

Nuestra atención a la dimensión acústica de la oralidad en el alabao resalta el carácter constitutivo de la escucha y la voz en la memoria sonora y en el poder de estos cantos. Ese poder del alabao consiste en: a) llevar a una unión afectiva con la muerte y a una expresión intensa que convoca a los ancestros (en el canto, en los sueños y en la velación) y a otros mundos; b) la solidaridad en el acompañamiento colectivo por el duelo, y c) su capacidad para construir vínculos reparadores entre los dolientes y su comunidad, entre los vivos y los muertos, entre mundos de vida y mundos de muerte. Esto nos llevó a definirlo así:

El alabao puede decirse que es como un tejido colectivo y ancestral cuyos versos se entrelazan como hebras siguiendo una puntada musical, cuya tonada tiene la capacidad de transmitir y de crear un sentimiento compartido de dolor, de solidaridad y de respeto por la muerte y las tradiciones. Esta capacidad de conmover que tienen los alabaos es lo que da ánimos a quienes asisten al velorio, al entierro y a la novena para vencer el cansancio, disipar la tristeza o el aburrimiento, y seguir acompañando a la comunidad en el dolor: unos alabaos dan ganas de cantarlos, otros conmueven profundamente y dan ganas de llorarlos. (Cantadoras de Pogue, Riaño-Alcalá y Chaparro 2016, 5-6) 


\section{Conmemoración y canto}

Iglesia de Bellavista Nueva, 2 de mayo del 2014, decimosegunda conmemoración de la masacre de Bojayá. Un grupo de veintiún cantadoras pogueñas cuyas edades oscilan entre los dieciséis y los noventa años están sentadas al frente de la iglesia, al lado del Cristo Mutilado ${ }^{11}$. Esperan el momento en que, durante el ritual conmemorativo anual de la masacre y en el oficio de la misa católica, se les invita a cantar. Cuando llega, se paran y Rosario, cantadora mayor y rezandera, invoca una de sus composiciones:

Para siempre sea el bendito,

eternamente alabao el cordero

sin mancilla.

Bojayá lo han condenado.

La poderosa voz de Rosario llena la iglesia. Los cerca de trescientos asistentes escuchan en un silencio profundo, mientras periodistas de diversos medios toman fotos y graban. Las mujeres, vestidas con blusas blancas y faldas negras, responden con un tono triste pero enfático la estrofa invocada, y así su canto se desenvuelve entre el llamado de la voz profunda y pausada de Rosario y el coro de mujeres que responde con fuerza y con el movimiento lento de un lado al otro de sus cuerpos:

El día del 2 de mayo

una pipeta cayó,

¡ay, cayó dentro de la iglesia

el cristo lo mutiló!

Esto quedó en el oscuro,

de la bala desplotada.

Como corría el agua

y era sangre derramada.

11 El Cristo Mutilado es el nombre con que los bojayaseños empezaron a referirse a la estatua que hacía parte de la iglesia de Bellavista. El cristo quedó en el suelo de la iglesia, en medio de cuerpos y escombros, sin brazos ni piernas tras la explosión que produjo la masacre del 2002. Es una de las imágenes que ha logrado una "significación social entre las víctimas y la comunidad de Bojayá", en la medida en que "expresa el impacto de la destrucción de la pipeta y de alguna manera representa la condición en que quedaron los cuerpos de prácticamente todas las víctimas y las lesiones de muchos sobrevivientes" (GMH-CNRR 2010, 297). La imagen se encuentra en una urna de cristal bajo el cuidado de las hermanas agustinas misioneras, se lleva a cada evento significativo de la comunidad y alcanzó alguna visibilidad nacional en septiembre del 2017 cuando, en un viaje de cuatro días, fue llevada desde Bojayá a la ciudad de Villavicencio para presidir la eucaristía celebrada por el papa Francisco en su visita a Colombia. 
En el canto de los alabaos, una cantadora pone o invoca un alabao y llama a las demás a que respondan. Susana, líder y cantadora, explica esta forma de canto repetitiva y responsorial que ella vincula a otro elemento central del que depende su poder afectivo, que se escuche bien.

La esencia del alabao es invocar, responder... o sea, invocar es una persona que es la primera que canta y responder lo que hacemos segundo, ahí esta la esencia para que se pueda escuchar bien, se tiene que hacer así invocando y respondiendo.

Así, el canto se constituye en un movimiento de puesta-respuesta que se sostiene hasta el final del alabao y que, como lo afirma Susana, requiere de una escucha que compromete el afecto y la conciencia (Riaño-Alcalá y Baines 2011). Las mujeres describieron este ejercicio de colocar el canto como uno en el que se conserva una sola voz, porque quienes responden deben coger el tono de voz de quien pone el canto. Este tipo de oralidad y práctica vocal se agencia desde un estilo participativo, así como desde rituales y expresiones estéticas, afectivas y simbólicas propias de estos movimientos de mezcla, resurgencia y resistencia cultural (De la Torre 2003; Tobón 2009; Valencia 2009). Pero lo que realmente motiva a responder, insisten las cantadoras, es el sentir de la tonada, el sentimiento que la cantadora le pone a su interpretación y que transmite en la potencia de su voz, a tal punto en que "el mismo dolor coloca el canto... la tristeza le da ánimos de colocar su canto" (taller 1, 2013). ¿Cómo se traduce entonces esta manera en que el dolor coloca el canto en una forma de movilización de la memoria y de acción política productiva en el día a día?

Como hemos anotado, la transformación del canto fúnebre en una composición para la memoria activa este campo de práctica política. Dicha transformación del alabao mediante la incorporación de composiciones hace parte del mismo quehacer y otros recursos culturales de las poblaciones afroatrateñas, que desde los siglos XVI-XVIII han transformado "géneros literario-musicales" en una variedad muy rica de poesía, música y canto. Durante siglos, estos procesos de renovación, hibridación y recreación de lo antiguo y lo nuevo han sido constantes (De la Torre 2003; Tobón 2016; Valencia 2009).

La composición como práctica poética, lírica y sonora de las cantadoras de Pogue oscila entre la iniciativa individual con algunas estrofas o un canto completo y el trabajo grupal de revisar la rima entre los versos y la adaptación musical y rítmica. Como lo han documentado Tobón (2016) y Tobón et al. (2015) en su amplia investigación sobre los romances y alabaos, estos no tienen una rítmica a la cual asociarlos y se tienden a cantar en el Atrato con una cierta libertad interpretativa. Para las mujeres de Pogue, el ritmo también es asunto de sentimiento y esto 
lo expresan en el lento movimiento de sus cuerpos, en la sonoridad de sus voces y en sus miradas fijas e intensas que comunican dolor y también determinación. La presentación de las primeras composiciones estuvo llena de zozobra por la reacción que pudieran tener los actores armados y políticos a las denuncias plasmadas en estos textos, pero paulatinamente este miedo fue equilibrado por el respaldo del grupo y de la comunidad en general. Al respecto, nos explicó Emiliana:

Nosotras sacábamos las coplas, pero con miedo, porque como, imagínese, los paramilitares y guerrilla [...] allá quién sabe en el momento que estamos en el 2 de mayo quién hay, quién escucha y que a uno lo sacan por los medios, por Caracol y todo, y que a uno lo van conociendo, y "vea, ellas son las que están haciendo denuncia, ahora las cogemos”. ¡Yo iba con miedo! Ahora sí yo ya no tengo miedo y siempre les digo si nos toca que nos vamos [...] que estamos denunciando y [si] le toca el grupo nos acaba[n] a todas... nos morimos todas y nos morimos por la verdad. (Entrevista 1, 2013)

Componer redimensiona la oralidad en un ejercicio de escritura y práctica vocal que incluye tanto el trabajo individual como el colectivo para construir memoria histórica propia y otorgarles nuevos sentidos a los eventos críticos de violencia vividos en el Medio Atrato. Santiago Arboleda (2011) resalta la oscilación y el dinamismo entre tradición oral y sonora así como su función histórica entre las poblaciones y los intelectuales negros como una muestra de la vitalidad del pensamiento afrodiaspórico.

Dicha oscilación también apunta a otro propósito que Constanza Millán (2009) reconoce en su exploración sobre la memoria y el canto en Bojayá: los alabaos se unen al repertorio de composiciones musicales de la región que incluyen el vallenato, las ragas y el rap, en un trabajo que apunta a la historización y reparación de la comunicación entre el tiempo y el espacio que fueron afectados por el horror y el sinsentido de la violencia, y que solo se hace posible en la transmisión de las emociones que facilitan el canto y la música. Sin embargo, en contraste con esas otras expresiones, las composiciones de las cantadoras las visibilizan y posicionan como autoras/compositoras e intérpretes colectivas, en contraste con otras expresiones musicales que, aunque también recogen experiencias individuales y colectivas de sufrimiento, su proceso característico de creación y performancia sitúan a un sujeto individual "que reclama ser compositor” (Millán 2009, 106).

Alllevar sentimientos, cantos y cuerpos a diversos escenarios públicos, las cantadoras ponen en movimiento su propio rechazo a los discursos dominantes que, si bien se estructuran como solidarios o de reconocimiento de las víctimas, mantienen una noción racializada de la víctima - como mujer y como minoría 
étnica-y del cuerpo femenino, como sujeto pasivo y sumido en el trauma. La representación que en medios y discursos oficiales se ha hecho de las cantadoras de Pogue se inscribe en estas lógicas de racialización y género que las sitúan en gramáticas restringidas del sufrimiento o de la reconciliación, que a la vez despolitizan sus cantos y puesta en escena. Las cantadoras rechazan estos discursos silenciadores de su agencia política y hacen del dolor el motor de sus modos de acción política. Las prácticas de canto y escucha y la poética del afecto desde las que trabajan interrumpen estas lógicas discursivas para posicionar sus cuerpos y emociones como fuerza reproductora de acción política y como caja afectiva de resonancias y memorias para cantar duro.

Resaltamos aquí la dimensión afectiva y simbólica del alabao, y en particular su recreación en composiciones para la guerra y la paz, porque permite explorar una veta expresiva de los mundos sonoros y poéticos de la región, pero en particular porque aporta pistas centrales para examinar el quehacer y la agencia política en el día a día de la guerra en esta región. La reflexión se inspira en el trabajo de Tina M. Campt (2017), quien se aproxima al registro sensorial, es decir, a las frecuencias silenciosas y sus resonancias como una manera de escuchar las imágenes fotográficas de personas negras a lo largo de trayectos históricos y geopolíticos diversos en África y Norteamérica. Integra también el llamado que Ana María Ochoa (2014) hace sobre la desatención que la dimensión acústica y la fuerza crítica de la escucha han tenido en estudios sobre la oralidad. Rastreando la frecuencia audible - la vibración periódica cuya frecuencia es audible para los seres humanos- en las imágenes que han sido históricamente rechazadas e ignoradas, el trabajo de Campt (2011) nos acerca al sonido y a la memoria sonora como registros afectivos encarnados. Se trata entonces de la escucha de las frecuencias musicales bajas - vibraciones, tonos, acentos y sentimientos- de estas prácticas vocales; de los lamentos, letanías y los rezos que acompañan el dolor constante por los muertos y desaparecidos a quienes no se les pudo adornar con alabaos, y de las frecuencias altas de las mujeres en conmemoraciones y eventos cuando les cantan duro y con sentimiento a los armados, a los políticos o al Estado. 


\title{
Mala muerte, duelo y reparación social
}

\author{
Nuestras almas no encuentran sosiego porque no hemos podido \\ hacer un auténtico duelo a los angelitos que perdimos, a las mujeres \\ embarazadas, madres, padres, hermanos, primos, sobrinos, abuelos, tíos y \\ tías que fueron arrancados de nuestro territorio.
} (Texto del Comité de Víctimas, 6 de diciembre del 2015) ${ }^{12}$

La magnitud de las atrocidades y el peligro que se vivió en el Medio Atrato, especialmente entre la década de 1990 y comienzos del 2000, dificultaron la posibilidad de realizar las prácticas ancestrales de duelo y entierro de los muertos. La recurrencia de lo que se nombra como la mala muerte, es decir, muertes violentas súbitas, desestabilizó profundamente los mundos cotidianos de las poblaciones negras, el equilibrio entre mundos de vivos y muertos y el descanso restaurador que permiten los rituales funerarios (Quiceno 2016). Este estado de inestabilidad activa una angustia colectiva por la imposibilidad de cumplir con los deberes de rezo, ritual y canto con que se restablece el balance entre la vida y la muerte cuando alguien muere (ACIA 2002; Oviedo 2018; Quiceno 2016).

Las comunidades y las familias se sienten profundamente perturbadas por la deuda que tienen con sus muertos y, en particular, por la falta de rituales fúnebres y entierros adecuados. Las mujeres de Pogue describen este desequilibro como un sentir de que la tragedia y la violencia les arrancan la fuerza del canto. Petrona, cantadora mayor, y sus hijas - también cantadoras-, contaron sobre sus propias reacciones emocionales cuando un señor de su corregimiento trajo a su esposa - quien murió en la masacre- para enterrarla y hacerle sus rituales fúnebres en Pogue. Sentadas en el frente de su casa, donde dos grandes altares con los santos de devoción de Petrona adornan las paredes y la acompañan en curaciones de huesos ${ }^{13}$, ella comenta:

12 Leído en Bellavista (Bojayá) durante el acto de reconocimiento de responsabilidades de parte de las FARC a la comunidad de Bojayá.

13 Además de su reputación como cantadora, Petrona también es reconocida como una de las sabedoras de la región al haber heredado un secreto con el que puede curar fracturas, torceduras y huesos rotos, por lo que también la llaman "la pegahuesos". Los pegahuesos tienen un conocimiento ancestral -un sistema médico ancestral afrochocoano basado en conocimientos y prácticas de los bantú (Mosquera 2000) - que Petrona guarda celosamente, tanto por su respeto a la tradición como por el poder que este representa. Así nos lo explicó cuando la entrevistamos en su casa en el 2013: "Yo no lo enseño. Siempre los que he curado me han propuesto plata y ahí sí mi corazón es malo, ni lo he vendido ni lo he enseñado... No es por egoísmo, sino, ¿saben por qué? Porque yo... a mí me lo enseñaron [...] Esas son unas palabras muy benditas para tener que ponerlas en un negocio". Este tipo de conocimiento y las prácticas de salud asociadas mantienen vigentes formas ancestrales de transmisión de 
Esa noche casi fue más silencio que lo que cantamos, de ver tristeza, y que nosotras sabiendo que había gente del pueblo de nosotras y que también estaban vueltas nada allá y allá tiradas que uno no sabía quién era, le digo que fue muy lastimoso, muy, muy lastimoso, no había esa fuerza. ¡Esa fuerza de la cantadora pues se le viene a según... yo le digo, a según uno tenga el dolor, digo yo eso! A según tenga uno mismo dolor así mismo es la fuerza, así mismo es. Esa noche el dolor era muy grande, no había fuerza para cantar.

La ausencia del ritual para las otras personas que fallecieron en la masacre, como lo documenta Constanza Millán (2009), afecta a quienes han fallecido e impide el descanso de sus almas, condenándolas a permanecer errantes en el mundo de los vivos. El impacto también es sobre los vivos porque el dolor no procesado, los ritos no cumplidos y la errancia en este mundo de quienes fallecieron les quitan fuerza vital a las personas y al canto.

La formación del grupo de cantadoras y las composiciones de coplas que le cantan al dolor fue la manera en que fueron encontrando nuevos sentidos. El canto les devuelve la fuerza y ellas toman esta poética del afecto para transformarla en una capacidad reparadora, en un acto que en sí mismo es ético y político (Million 2009). Las cantadoras de Pogue recrean el repertorio ancestral de los alabaos, primero formando un grupo de cantadoras (previamente se juntaban cuando alguien moría, pero sin tener una presencia definida o estructurada como grupo) y, segundo, mediante las composiciones poéticas y rítmicas de coplas que narran el dolor y visibilizan los hechos de violencia que se vivieron en la región. El canto de alabaos en conmemoraciones o en otros eventos y la presencia ritual y grupal de las mujeres se constituye en una forma de equilibrar el exceso de mala muerte que se sufre en tiempos de guerra y en mecanismos de reparación social (Quiceno 2016).

Los ritos fúnebres de los afrochocoanos son también prácticas del cuidado hacia los dolientes y de quienes han muerto, que se procuran durante "el recorrido" del velorio y las nueve noches en que se reza, se cantan alabaos y santodios, se reparte café con pan, se consume viche para darle fuerza al canto y se despide a la persona fallecida. Familiares, amigos y paisanos están presentes en el velorio; “ese día todo el mundo se va, se une al dolor suyo” para acompañar a familiares y a la persona que falleció. Cristina, una de las cantadoras, explica estas prácticas del cuidado a través del canto y de la presencia en el velorio, "de mostrarle a la

conocimiento como el secreto y la comunicación en sueños. A la vez, incorporan elementos de la medicina popular europea, de prácticas embera y, más recientemente, de la medicina alopática y naturista. 
persona que estamos ahí con él en ese momento difícil”. Estas prácticas de cuidado que tramitan los rituales fúnebres y la organización de parte de la comunidad del entierro y del velorio fueron también profundamente afectadas durante el recrudecimiento de la guerra en la región. Por ello las cantadoras ven que su oficio y presencia en las conmemoraciones crean un espacio afectivo y de cuidado para expresar las emociones. Comenta Rosario:

Son coplas con ritmo de alabao y que de pronto se pueden hacer cantados a lo que [ha] sucedido, pero teniendo en cuenta que como ellos no pudieron, no pudieron aprovechar la tradición uno aunque haga las coplas, pero los pone en forma de alabao para que esa gente también aproveche o tenga el fruto de sentir algo, uno de mostrarles que uno también sintió algo de ellos, así.

Como lo anota Sarah Ahmed (2004), las emociones dan forma a los cuerpos como ejes de acción y de orientación hacia otros, en este caso, el de las cantadoras como cuidadoras. Las cantadoras han transformado emociones encarnadas de miedo, tristeza, amor y rabia en un saber incorporado en sus cuerpos que reconoce los efectos de las violencias. Son cuerpos que cantan y hablan duro, y que acuden a un repertorio de fuerzas y valores para procurar cuidado y abrir espacios para la expresión del dolor y la rabia. El cuidado, en el contexto de una región en el que la violencia continúa, opera como una acción que restaura parcialmente relaciones y espacios para elaborar duelos y cumplir con los deberes morales hacia quienes han muerto, y es una manera en que las cantadoras asumen su responsabilidad hacia sus comunidades (Gutiérrez 2016).

Para los dolientes y asistentes a las conmemoraciones, las cantadoras han compuesto y puesto en escena textos, frecuencias sonoras y gestualidades con las que cantan duro y desde el sentimiento. Esta práctica, que ellas nombran como de denuncia, tiene también un sentido reparador de la mala muerte por la capacidad de evocar sentimientos en quienes la escuchan y un reconocimiento del dolor: se canta para conmover, pero esto se hace con voz fuerte para que se escuche su mensaje. En el undécimo aniversario, las coplas que compone e invoca una de las cantadoras mayores interpelan desde este lugar a quienes las escuchan, pero se dirigen en particular a medios de comunicación y actores armados:

Y undécimo aniversario

y esto quedó pa la historia,

díganle a los de la prensa

que no borren la memoria.

Díganle a los de la prensa

que no borren la memoria. 


\begin{abstract}
Y eso quedó pa la historia
y nunca se olvidará,

señores grupos armados,

no vuelvan más por acá,

señores grupos armados,

no vuelvan más por acá.
\end{abstract}

Como puede rastrearse en estas coplas, las composiciones comunican juicios morales y políticos. De esta manera, el movimiento y el proceso desde la composición en los días previos al evento por parte de alguna de las cantadoras mayores, su corrección y sus modificaciones durante la práctica grupal, hasta la puesta en escena en un escenario público, moldean una ecología de prácticas en las que tanto el afecto y el cuidado como la denuncia e interpelación actúan como fuerzas reparadoras de las relaciones con los mundos de la vida y la muerte, y como activadoras de formas de acción política productiva y visceral (Vergara-Figueroa 2017).

La presencia frecuente de delegados oficiales en un territorio tan "remoto" y olvidado del país central responde a muchas razones, pero en particular a la manera en que Bojayá es construido por el Estado colombiano como caso emblemático de las atrocidades de las FARC - este grupo lanzó la pipeta que tenía como blanco a los paramilitares pero cayó en la iglesia donde los civiles buscaban refugio-y como ejemplo de la voluntad gubernamental de reparar a las víctimas -fue uno de los primeros casos en los que se tomaron medidas de reparación-14. Así, Bojayá se convirtió, en el discurso oficial del Gobierno y las fuerzas armadas, en el ejemplo de la atrocidad y el terrorismo de las FARC. Sin embargo, el repertorio de responsabilidades de estos hechos compromete también a organismos del Ejército y la Policía por la complicidad y connivencia de algunos de sus miembros con el bloque paramilitar Élmer Cárdenas que operaba en esta región, y al Estado por el fracaso al responder a los llamados de alerta de la comunidad y 
de las organizaciones de derechos humanos sobre la inminencia de un desastre. No obstante, los discursos de culpabilidad, responsabilidad y explotación del sufrimiento con el que Bojayá se nombra en comunicaciones gubernamentales o en los reportes mediáticos no se sustentan en el reconocimiento de las responsabilidades. Como sostiene Aurora Vergara-Figueroa (2017), estos discursos perpetúan un silenciamiento histórico sobre las poblaciones negras e indígenas.

Resaltemos aquí la poética y la política del afecto en la que toman lugar estas prácticas creativas de memoria sonora y de acción política en medio de la guerra. La forma en que se canta el alabao en Pogue es reconocida en la región como única, no solo por la composición de nuevos contenidos y melodías para el alabao, sino en particular por la forma en que la cantan con fuerza y sentimiento. Su canto está pausado e impulsado por la invocación de las letras que narran la violencia o el dolor, pero en particular por la fuerza transformadora de las emociones que se detienen en un sentimiento.

Esta invocación de la emoción es para las cantadoras profundamente encarnada y emplazada, es "lo que estremece el cuerpo a uno", "lo que tiembla a través de nuestro cuerpo”, “una sensación profundamente sentida” que convoca a otros sobrevivientes a la elaboración del duelo y se ofrece como dispositivo reparativo de las rupturas y desbalances de mundos de vida y muerte generados por las malas muertes en la guerra. De esta manera, estas composiciones crean un entorno acústico que convoca a la fuerza crítica de la escucha y como modo de participación activa (Ochoa 2014). Como ha señalado José Óscar Córdoba (2009), para los pueblos afrochocoanos el cuerpo guarda secretos, olvidos y memorias del África negra y de la esclavitud, que en la música, el canto, el rezo y la danza se conectan con lo sagrado y con un colectivo de otros cuerpos que también se comunican a través del movimiento o el canto. Las cantadoras renuevan estas prácticas reparadoras mediante la mezcla de poesía cantada y de memoria para crear un entorno afectivo que ayude a otros a compartir el dolor y a responder al exceso de muerte y pérdida. A esto lo entendemos como acción reparadora. La reparación social, según muestra Omer Aijaizi (2018), también trata sobre cómo lo espiritual, las vidas futuras y pasadas, los muertos y los vivos se reintegran en una red de relaciones.

Como hemos visto, esta poética y política del afecto y la reparación están en el núcleo de los rituales de vigilia, tal como se practican en la región, pero además están hermanadas y entrelazadas en una ecología afectiva de prácticas arraigadas en un territorio formado y marcado por los ríos que se perciben como seres vivos y sintientes y lugares-actores centrales en el quehacer cotidiano. Además de su centralidad como vehículo base de la producción, la economía, la red 
alimentaria y el desplazamiento, los ríos en la región son un referente vital del sentido de pertenencia e identidad (las personas se identifican por el río del que vienen) y agentes vitales del paisaje sonoro de la memoria; se habla así del río que baja cantando ${ }^{15}$. Embarcarse, como lo han documentado los trabajos de Constanza Millán (2009), Natalia Quiceno (2016) y William Villa (1998), tiene un profundo significado cultural y es una práctica que organiza el universo ontológico, es decir, la manera en que se entiende cuáles son los seres y entidades que constituyen el mundo, y las prácticas organizativas de reconocimiento del territorio o encuentros organizativos de las poblaciones afros e indígenas ribereñas ${ }^{16}$.

También es el río desde y adonde llega la violencia: las prohibiciones de circular por este, los retenes, los muertos que también bajan por él. La irrupción de la violencia y la mala muerte se narran localmente en sus efectos sobre el río. En estos relatos el río se muere y la fuerza que viene del movimiento se aquieta. El incremento de las inundaciones se explica también por el recrudecimiento de la violencia y, como lo documenta Natalia Quiceno (2016), la lucha por el territorio $^{17}$, contra la guerra y a favor de la restauración de estas corrientes de relaciones, se concibe como un asunto de ponerse en movimiento, de embarcarse:

Todas las luchas descritas en este trabajo acuden al movimiento, al embarcarse para desafiar la quietud y el cierre del río que proponen los armados. El movimiento activa diversas formas del territorio y actualiza las relaciones, pero al mismo tiempo impide el endurecimiento de las mismas. Mantener el movimiento o permanecer embarcado aparece como una forma de hacer la política que resiste a la concentración y jerarquización del poder. (305)

Como lo captura el título del trabajo etnomusicológico de Alejandro Tobón y su equipo (Tobón et al., 2015).

Ulrich Oslender (2016) examina esta íntima asociación entre la historia de defensa del territorio, la organización de comunidades por ríos y las prácticas de desplazamiento del río como mecanismos de afirmación territorial de los movimientos sociales de la costa pacífica colombiana (en particular, en los ríos San Juan, Guapi y Guaji).

17 La lucha por la defensa del territorio y de los ríos tiene una larga trayectoria en la región. Se remonta a los años 1970 y los 1980 con la conformación de organizaciones por la autonomía y defensa territorial, como la Asociación Campesina Integral del Atrato (ACIA), la Organización Regional Embera-Wounaan (Orewa) y la Asociación de Cabildos Autoridades Tradicionales Indígenas Embera Dóbida, Katío, Chamí y Dule del departamento del Chocó (Asociación Orewa). En 1997, la ACIA recibió el título legal de una gran extensión del territorio en representación de 120 organizaciones bajo la Ley 70. Con la agudización del conflicto armado en la región en los años 1990 y los 2000, estas mismas organizaciones y los consejos comunitarios continúan su trabajo de defensa del territorio y resistencia frente a la presencia de actores armados y acciones de violencia y desposesión de sus territorios. Véanse Villa (1998), Escobar (2008) y GMH-CNRR (2010). 
Los alabaos que cantan las mujeres pogueñas y sus composiciones se embarcan también en un movimiento que busca restaurar mundos y relaciones desde el sentimiento. Otras dos coplas de alabaos compuestos por Emiliana para el undécimo y duodécimo aniversario ubica al río como referente territorial:

Con esta nos despedimos, ya no les cantamos más, que se acabe la violencia en el río e Bojayá, que se acabe la violencia, no vuelvan más por acá, que se acabe la violencia no vuelvan más por acá.

(Undécimo aniversario, Bojayá, mayo del 2014)

A todos los presidentes, manden con honestidad, que en el río Bojayá esto no vuelva a pasar.

(Duodécimo aniversario, Bojayá, mayo del 2015)

Las cantadoras hacen del canto y de la escucha un laboratorio de trabajo con las emociones para transformarlas en fuerza para el cuidado y en dispositivos para la acción: ellas se detienen en el dolor, le cantan al dolor y traen el dolor como la emoción que se transforma en sentimiento, en una conciencia afectiva de la necesidad de reparar sus mundos y de evitar que la violencia continúe destruyéndolas y silenciándolas. Así, la expresión citada de Martha de que les nace un sentimiento indica el poder y agencia de este, así como su carácter generador de las vidas políticas de los alabaos y las cantadoras. Además, porque el canto emplazado en el ritual (de la conmemoración o de las nueve noches) se torna en dispositivo de sentimiento y expresión acústica para que los dolientes se vean también como sujetos y actores de sus vidas (Quiceno 2016; Rutherford 2016). La ética del afecto que estas acciones sugieren resulta de reconocer las emociones del dolor, la rabia y el miedo, así como su impacto subjetivo, y se trae al canto con toda la fuerza sonora, expresiva y encarnada con la que comunican a otros el dolor que se sufre y el rechazo a la violencia. 


\section{Lugares y poéticas de la conmemoración, el cuidado restaurador y la rememoria}

2 de mayo del 2018, 1 p. m. Bojayá, Bellavista Viejo ${ }^{18}$, en el Medio Atrato chocoano. La ceremonia y misa de conmemoración del decimosexto aniversario de la masacre de Bojayá terminan y la mayoría de las delegaciones oficiales, las internacionales, las religiosas, las comunidades ribereñas del Medio Atrato y los periodistas abordan las pangas o embarcaciones de madera gigantescas que regresan a Bellavista Nuevo. Un grupo de aproximadamente veinte personas (entre sobrevivientes, líderes, cantadoras y rezanderos e investigadores) tomamos dos pangas hacia la fosa común, el primer lugar donde se enterró a los que murieron en la masacre. Por el alto riesgo que se vivía, fue un entierro apresurado y carente de los rituales propios.

Luego de un trayecto a pie relativamente corto se encuentra la fosa que está cerca de la orilla del río. Cuando el grupo llega al lugar, se ubica formando un círculo a su alrededor. Susana invoca un alabao y otras cantadoras responden. Manuel y Rosario, los rezanderos que las acompañan, guían las oraciones. A continuación algunos sobrevivientes dicen unas palabras y, mientras hablan, Estebana, abuela y madre que perdió en la masacre a ocho de sus nietos, un hijo y tres nueras, "una familia grandísima que cayó ahí”"19, recoge un palo largo y unas ramas. Improvisa con ellos una escoba y empieza a limpiar, a organizar "el desorden”, dice. Repite varias veces que esa no es la manera como se mantiene el lugar a los muertos. "Esta es su casa”, dice. En la fosa, sin embargo, no hay restos: unas semanas después de ocurrida la masacre fueron trasladados al cementerio de Bellavista Viejo y de allí, con los años, varios de ellos fueron trasladados a los cementerios de Bellavista Nuevo, Riosucio y Pogue ${ }^{20}$. Por lo tanto, aquella primera e improvisada fosa permanece vacía.

La reubicación y construcción de Bellavista que ya se explicó llevó a sus habitantes a distinguir entre Bellavista Nuevo y los restos del antiguo pueblo, a los que se refieren como Bellavista Viejo.

Véase la entrevista a Estebana en https://www.youtube.com/watch?v=Xx8OBtVRw7k

Entre el 6 y 12 de mayo del 2002 un equipo técnico de la Fiscalía y Medicina Legal visitó la fosa para realizar la identificación de restos y otros registros forenses. Los cuerpos que se iban identificando eran dispuestos en bolsas plásticas y enterrados en fosas individualizadas en el cementerio de Bellavista. Las labores se suspendieron cuando iban en un $80 \%$ de su ejecución, por razones de seguridad, pero fueron completadas en una segunda visita en junio del mismo año (diario de trabajo de campo, 2010; Ospina 2004). 
Pero la presencia de los muertos en el lugar pervive para Estebana. Su memoria cargada como imagen y presencia espectral estimula el deber moral de ella y la determinación de quienes están allí de dar cumplimiento a una ética del afecto y de relaciones que les permitan reparar sus deudas y deberes con los muertos, especialmente con estos marcados por el sino de la tragedia y de la mala muerte. También alrededor de la fosa está la determinación de los integrantes del Comité de Víctimas de marcar este sitio como lugar de memoria.

En mayo del 2018, si bien se habían hecho las exhumaciones de los cuerpos en los cementerios a los que se trasladaron los restos, la comunidad aún esperaba su plena identificación y la rendición de cuentas sobre quienes continúan desaparecidos para poder llevar a cabo los ritos finales y darles el debido estatus de ancestros vivos ${ }^{21}$. Las acciones de limpieza, rezo y canto, el embarque hacia la fosa y su inscripción como lugar de memoria se arraigan en la presencia espectral y continua de los muertos para llevar a cabo una acción que es tanto reparativa como restauradora. Y aquí es cuando la forma de evocar a los muertos se agarra de su imagen, de una memoria que es rememoria porque trae una imagen y una presencia continua de lo que ha desaparecido o ha sido olvidado.

La nobel de literatura Toni Morrison, en su obra Beloved (1987), utiliza la idea de rememoria para nombrar aquello que está más allá de la experiencia original, esa imagen que persiste pero a la vez ha desaparecido. Los restos de quienes perecieron en la masacre ya no están allí, como no están sus nombres $y$ vidas en el registro de la memoria de los colombianos. Pero, para Estebana, su presencia e imagen continúan en el lugar, en su casa. La rememoria, nos dice por su parte la poeta Juliane Okot-Bitek (2019), trabaja contra el olvido y el silenciamiento de la historia y la conciencia mantenida por los regímenes de guerra y violencia estructural. La rememoria no depende de la documentación, o incluso de la narrativa, porque es una forma de resistencia en el aquí y ahora y en el registro histórico y que se agarra a la imagen - a esa presencia arraigada en el lugar- en contra del dominio del archivo (Okot-Bitek 2019).

Estas formas de conmemoración social descritas para el Medio Atrato -invocar, cantar, cuidar a los muertos, limpiar la casa-permiten abrir la reflexión hacia otros sentidos y prácticas conmemorativas que se tejen y ponen en escena en estos espacios, así como a las ausencias y presencias que, como trazos de otros mundos, continúan estando presentes en el día a día de los habitantes de la región.

21 Como lo documenta Ana Gilma Ayala (2011), el concepto afrochocoano de la ancestralidad convierte al difunto en un resucitado que tiene presencia en el día a día atrateño: "por eso no a todos se les considera ancestros, sino aquellos que en su vida supieron aconsejar" (25). 


\section{Fricciones e interpelaciones}

La petición de perdón no debe dirigirse solo a nosotros, sino además, a todos los pueblos afrocolombianos e indígenas de la región del Pacífico, pues nuestra situación de víctimas se replica, de diversas formas, a lo largo del Chocó biogeográfico. (Comunicado de los representantes de las víctimas de Bojayá a la mesa de negociación con las FARC en La Habana, 18 de diciembre del 2014) Con esta "ración" de sentimientos queremos saludar la presencia de los representantes de las comisiones de la Mesa de Diálogos de Paz, ante quienes queremos ratificar que este proceso de búsqueda de reconciliación debe empezar y consolidarse con gestos concretos de garantías de no repetición.

(Pronunciamiento del Comité de Víctimas de Bojayá, 6 de diciembre del 2015)

Espacios performativos como la conmemoración anual de la masacre ponen también en escena las fricciones y contradicciones de los discursos de paz y reparación, y las formas en que el grupo de cantadoras construye su quehacer político en estos espacios (Jaramillo 2014). Esto se puede ver más claramente en otros dos eventos que tuvieron lugar entre el 2014 y el 2016: el reconocimiento de responsabilidades y pedido de perdón de las FARC a Bojayá y la firma del acuerdo nacional de paz entre el Gobierno colombiano y las FARC. Las cantadoras fueron invitadas a ambos eventos.

Después de más de cincuenta años de guerra, en noviembre del 2016 se llegó a un acuerdo de paz entre el Gobierno colombiano y las FARC, la guerrilla más antigua y grande de las Américas ${ }^{22}$. En medio de las negociaciones de paz en el 2014, miembros de la comunidad de Bojayá fueron invitados a La Habana —donde se llevaban a cabo los diálogos - con el fin de que las FARC realizaran su primer reconocimiento de responsabilidades por las atrocidades cometidas y pidieran perdón. Esto era crucial para avanzar y demostrar la voluntad y el compromiso de las FARC con el proceso de paz, por el peso político y simbólico que Bojayá tiene para el Gobierno, el Ejército y otras instituciones oficiales como crimen paradigmático de la guerra en Colombia. Si bien la comunidad aceptó la

22 En agosto del 2016 las FARC acordaron con el Gobierno un cese bilateral del fuego, como parte de un tropezado proceso de negociación que había iniciado informalmente en el 2010 y formalmente en el 2012. Tras seis años de negociaciones en los que continuaba la confrontación armada, las partes firmaron el Acuerdo Final para la Terminación del Conflicto y la Construcción de una Paz Estable y Duradera. 
invitación, los miembros que viajaron aclararon a la mesa que ellos no podían aceptar el perdón sin consultar a las comunidades indígenas y afrocolombianas del Medio Atrato afectadas por estas acciones. Las personas delegadas de Bojayá fueron para escuchar el mensaje de las FARC y posteriormente consultar con las comunidades ribereñas sus condiciones y criterios para aceptar o no la solicitud de perdón de las FARC. Siete meses después de la visita a La Habana, una delegación de las FARC liderada por Félix Antonio Muñoz Lascarro (alias Pastor Alape), hasta entonces miembro del secretariado de las FARC y su vocero en la negociación de paz, viajó a Bojayá el 6 de diciembre del 2015 para presentar formalmente, en un acto simbólico, la solicitud de perdón de esta guerrilla a la comunidad de Bojayá y el reconocimiento de su responsabilidad.

El lugar del acto simbólico fueron las ruinas del edificio aledaño a la iglesia de Bellavista Viejo donde cayó la pipeta. Los representantes de las FARC, del Gobierno e instituciones fueron ubicados en una fila de sillas de espaldas a las ruinas del edificio donde se había puesto el telón con los nombres de las víctimas tejido por las mujeres del grupo Guayacán en los años posteriores a la masacre ${ }^{23}$. Al frente, en un semicírculo de filas de sillas blancas, se sentaron personas de la comunidad y algunos acompañantes. El evento lo protegió la Guardia Indígena Embera Dovida de la región, cuatro integrantes de la Guardia Indígena Nasa del norte del Cauca y algunos integrantes de la recién creada Guardia Cimarrona (Orjuela 2016).

Las cantadoras se embarcaron desde Pogue para estar presentes en el evento. Cuando llegó su turno en el programa, se hicieron a un lado y, al frente de los representantes de las FARC, los representantes del Gobierno y las instituciones. Emiliana, parada unos pasos adelante del grupo, invocó un alabao que compusieron para el quinto aniversario de la masacre y al que le hicieron "arreglos” para este acto. Con movimientos enfáticos y dando unos pasos hacia delante y otros hacia atrás, su mirada puesta en la delegación y en Pastor Alape, Emiliana agitó rítmicamente sus brazos en alto y firmemente hizo el movimiento del no con su mano.

Señores grupos armados,

no nos causen más dolor.

El resto del grupo responde:

Señores grupos armados, no nos causen más dolor.

23 El telón de los sueños y las esperanzas fue producto del trabajo de las mujeres del Grupo de Artesanías Guayacán, "con el bordado de los nombres de sus víctimas en pedazos de tela llenos de color, naturaleza y mensajes para la vida” (Orjuela 2016). 


\section{Emiliana invoca nuevamente:}

La toma del dos de mayo,

y eso quedó pa la historia.

Letra, movimientos y su mirada se repitieron hasta que finalizó el alabao. Las frecuencias sonoras de este registro del canto se sienten en el cuerpo de Emiliana y en el de las cantadoras. Este es un momento de alta frecuencia sonora, de denuncia. A continuación, Martha invoca otro alabao. Ella pone el canto y a ratos su mirada se fija en los delegados de las FARC y el Gobierno, y en otros baja sus ojos mientras entona con solemnidad:

Estamos en la iglesia unidas de corazón

y los que hicieron el daño, amén,

no sienten el dolor.

Señores de los grupos armados, les pedimos de corazón:

que reparen los daños

causados en nuestra región.

El murmullo cantado y sentido del dolor se registra en esta frecuencia más “baja” y silenciosa y del imperativo de actuar que comunican. Llama a la escucha cuidadosa y afectiva porque ofrece una entrada a estas composiciones y puesta en escena como relatos y memorias alternas de la guerra (Campt 2017) y como conocimiento situado. Vergara-Figueroa (2017) llama a estos modos de cantar políticas de la espiritualidad. En este artículo nos hemos enfocado menos en la dimensión espiritual del alabao para trabajar principalmente su dimensión afectiva y actante.

Las cantadoras han aprovechado todas las oportunidades para comunicar y hacer de su canto una práctica afirmativa de rechazo al no reconocimiento de las responsabilidades y a los gestos vacíos. Los cantos interpelan a las delegaciones presentes a la vez que comunican su oposición al llamado de perdón y reconciliación cuando la región y sus vidas continúan siendo militarizadas, y la incertidumbre, las amenazas y el miedo prevalecen. Las cantadoras y las comunidades ribereñas, a las que el Comité de Víctimas de Bojayá ${ }^{24}$ consultó por meses sobre la solicitud de perdón por parte de las FARC, desafiaron la idea de que el gesto necesario era el perdón. Por el contrario, sus exigencias fueron: el reconocimiento de responsabilidad de cada actor sobre las violaciones y crímenes cometidos, que se demuestre compromiso con la no repetición de esos actos y el cese de las acciones contra la comunidad. Recuerda una cantadora: "Le metimos

24 El Comité de Víctimas de Bojayá se creó en el contexto de estos diálogos. Aglutina organizaciones comunitarias y asociativas, así como a grupos de jóvenes de la región. 
una estrofita ahí que dice: "la guerrilla de las FARC hoy quiere pedir perdón, los colombianos pedimos que no más repetición”.

Meses más tarde, en la sede del grupo de mujeres Guayacán en Bellavista, Fátima y Emiliana describieron ese momento y recordaron el miedo que sintió Emiliana, “porque yo había sido la que había cantado adelante”. Fátima: "Y lo señalaba, porque ella [Emiliana] lo señalaba con su mirada. Y yo: [...] “¡No vuelvan más por aquí y no vuelvan más por aquí!”.

Cuando fueron invitadas al evento nacional de la firma del acuerdo de paz en noviembre del $2016^{25}$, expresaron que eran conscientes de que, en un momento tan trascendental para las millones de víctimas del país, ellas fueron la única voz presente de los sobrevivientes y afectados por la guerra, y que los cinco minutos asignados para su canto les ofrecían un gran escenario público, nacional y mediático. En este espacio, vestidas con blusas blancas, unas flores de color violeta en su pecho y faldas negras, ocho cantadoras entonaron con fuerza y sentimiento su compromiso con la paz, llamaron a la no repetición e instaron al Gobierno y a todos los colombianos a asumir responsabilidad con el proceso de paz. Conscientes de que su canto y presencia tenderían a ser interpretados bajo discursos victimizantes y sus cuerpos apropiados como símbolos despolitizados de la reconciliación, seleccionaron cuidadosamente lo que cantarían. Recuerda una de las líderes afro sobreviviente de la masacre de Bojayá:

No, y hubo cosas muy importantes que tuvo ese acto, y es que el acto por su forma y la cosa en Cartagena, ya sabemos todo lo que se mueve detrás de Cartagena y todas esas cosas, que el mun[do]... que Colombia no quería mostrar unas realidades [risa] y estas mujeres finalmente fueron la voz de las víctimas, fueron las únicas voces que tuvieron las víctimas, que tuvimos las víctimas en esa firma.

Tres de las mujeres cantaron alabaos que fueron ajustados para los cinco minutos que les dieron. Rosario, cantadora mayor y rezandera, invocó,

Oiga, señor presidente,

venimos a felicitar

por su grande valentía

y a trabajar por la paz.

Y el grupo respondió:

Por su grande valentía

25 El primer evento público de firma del acuerdo de paz fue el 26 de septiembre del 2016 en Cartagena. Por el resultado negativo del plebiscito para refrendarlo, el 24 de noviembre del 2016 se firmó en la misma ciudad un segundo acuerdo, con los cambios introducidos a raíz de la negociación con sectores opositores. 
y a trabajar por la paz.

Santa María: danos la paz (bis).

Rosario invoca nuevamente y traza con su canto el sentido y la lógica histórica de las comunidades negras y el pensamiento afrocolombiano, el que conecta las historias de violencia reciente con la larga duración de su explotación y sufrimiento como comunidades negras e indígenas:

Y quinientos años

sufrimos este dolor.

Pedimos a los violentos

no más repetición...

\section{Cierre}

En este artículo nos hemos aproximado a las prácticas y modos de componer y cantar el alabao en el Medio Atrato como una poética del canto y una política del afecto y del cuidado. El canto de alabaos en la región pone en escena unas prácticas resurgentes de las mujeres negras afroatrateñas y cuyo poder en la elaboración colectiva del dolor radica en tres fuentes: 1) la inscripción en un repertorio de tradiciones ancestrales y conocimiento encarnado en formas de acción política; 2) la performancia del canto bajo una frecuencia afectiva y como tejido generador de poética y política de la memoria; y 3) el sentimiento desde el que se canta y se transmite.

El movimiento que intentamos trazar aquí es el que busca poseer y controlar al cuerpo de estas mujeres negras en el contexto de un régimen transicional de justicia y verdad y racializado, como los cuerpos sobre los que se inscriben la reconciliación y los gestos de paz (en el caso de las conmemoraciones o eventos públicos). Se trata de un movimiento que pretende apropiarse del cuerpo y las voces de las cantadoras como víctimas modelo: complacientes de las solicitudes de perdón y símbolos de la reconciliación o del sufrimiento. Las cantadoras interrumpen ese guion con otros movimientos que sitúan sus cuerpos en una ecología afectiva de prácticas relacionales que busca reparar sus deudas y deberes con los muertos y que rechaza -mediante el canto y su puesta en escena- su representación y apropiación como sujetos pasivos o ejemplarizantes de la reconciliación.

Entonces, ¿cómo moldean estas prácticas corporales las formas en que el pasado se narra y se negocia en estos espacios críticos de encuentro y fricción 
con el mundo institucional o con otros sobrevivientes? Hemos recurrido a las nociones de registro afectivo y rememoria para describir la inscripción de la memoria sonora y la poética del afecto en los cuerpos de las cantadoras. Los alabaos de esta manera recrean significado y activan la fuerza de los sentimientos: trazos materiales y encarnados desde los que se retiene y transmite la memoria y se ponen en acción las prácticas de interpelación y rechazo. Pero, más aún, hemos llegado a apreciar la creación de este paisaje afectivo y acústico como un proceso colectivo continuo de creación y restauración de relaciones y medios por los cuales se sostienen mundos frente a las fuerzas de las intervenciones estatales e institucionales. Estas prácticas de memoria sonora ofrecen a los sobrevivientes un marco narrativo y conceptual para vivir e interactuar con sus mundos sociales y paisajes de memoria, pero también para gestionar la política y poética del afecto, del hablar duro y con sentimiento, en sus interacciones y negociaciones con los regímenes de verdad y las instituciones de la justica y la paz en periodos transicionales.

\section{Referencias}

ACIA (Asociación Campesina Integral del Atrato, Chocó). 2002. Medio Atrato. Territorio de vida. Bogotá: Red de Solidaridad Social.

Ahmed, Sarah. 2004. The Cultural Politics of Emotion. Edimburgo: Edinburgh University Press.

Aijazi, Omer. 2018. "Fictions of Social Repair: Chronicity in Six Scenes”. Tesis de doctorado, University of British Columbia, Vancouver.

Arboleda Quiñónez, Santiago. 2011. "Le han florecido nuevas estrellas al cielo: suficiencias íntimas y clandestinización del pensamiento afrocolombiano”. Tesis de Doctorado en Estudios Culturales Latinoamericanos, Universidad Andina Simón Bolívar, Santiago de Cali, Colombia.

Arocha, Jaime. 2009. "Homobiósfera en el Afropacífico”. Revista de Estudios Sociales (32): 86-97. http://journals.openedition.org/revestudsoc/16539

Ayala, Ana Gilma. 2011. Rituales mortuorios y afroatrateños en el alto y medio Atrato. Medellín: Mundo Libre.

"Bojayá, un símbolo del dolor que le apostó a la paz y ahora teme el regreso de la guerra”. 2016. New York Times, 12 de octubre. https://www.nytimes.com/es/2016/10/12/bojaya-unsimbolo-del-dolor-que-le-aposto-a-la-paz-y-ahora-teme-el-regreso-de-la-guerra/

Campt, Tina. 2017. Listening to Images. Durham: Duke University Press. 
Cantadoras de Pogue, Pilar Riaño-Alcalá y Ricardo Chaparro, comps. 2016. El oficio de cantar memoria. Las Musas de Pogue. Grupo de Cantadoras Pogue, Bojayá, Chocó. Bogotá: University of British Columbia; Cocomacia.

Clarke, Kamari Maxine. 2009. Fictions of Justice: The International Criminal Court and the Challenges of Legal Pluralism in Sub-Saharan Africa. Cambridge; Nueva York: Cambridge University Press.

Comité por los Derechos de las Víctimas de Bojayá. 2019. “Disposición de los cuerpos en el mausoleo". Inédito.

Córdoba, José Oscar. 2009. Resistencia festiva: fiesta de San Antonio de Padua en Tangui (Chocó) en el contexto del conflicto armado (1996-2008). Bogotá: Ediciones Uniandes.

De la Torre, Gonzalo. 2003. "El alabao. Expresión de vida, herencia cultural afro-pacífica. Un hombre y un pueblo concreto". Folleto del CD Alabaos (Centro Cultural MAMA-U de Quibdó, Chocó). En Historia del pueblo afrocolombiano, perspectiva pastoral (anexo 3). Popayán: Centro de Pastoral Afrocolombiana (Cepac).

Equitas (Equipo Colombiano Interdisciplinario de Trabajo Forense y Asistencia Psicosocial). 2018. "Caso Bojayá: informe de análisis de contexto. Análisis forense de los decesos asociados a la estrategia militar para el control territorial”. Inédito.

Escobar, Arturo. 2008. Territories of Difference. Place, Movements, Life, Redes. Durham: Duke University Press.

Friedmann, Susana. 2006. "Cantadoras que se alaban de poetas. Reivindicaciones colectivas en la construcción de cultura”. Palimpsesto 1: 142-147. http://www.bdigital.unal.edu. co/14249/1/3-8070-PB.pdf

GMH-CNRR (Grupo de Memoria Histórica-Comisión Nacional de Reparación y Reconciliación). 2010. Bojayá: la guerra sin límites. Bogotá: GMH-CNRR; Fundación Semana; Taurus. http://www.centrodememoriahistorica.gov.co/descargas/informes2010/informe_ bojaya.pdf

Gómez Nadal, Paco. 2012. Los muertos no hablan. Bojayá, una década (2002-2012). Quibdó: Fundación Universitaria Claretiana. https://www.traficantes.net/sites/default/files/pdfs/ los-muertos-no-hablan.pdf

Gutiérrez, David. 2016. “Ejercicios del cuidado. A propósito de La piel de la memoria”. Tesis de Doctorado en Historia del Arte, Universidad Nacional Autónoma de México, Ciudad de México.

Jaramillo, Pablo. 2014. Etnicidad y victimización. Genealogías de la violencia y la indigenidad en el norte de Colombia. Bogotá: Ediciones Uniandes.

“Jorge Luis Mazo-Sacerdote”. 2009. Verdad Abierta, 28 de agosto. https://verdadabierta.com/ jorge-luis-mazo-sacerdote/

Losonczy, Anne Marie. 1991. "El luto de sí mismo. Cuerpo, sombra y muerte entre los negros colombianos del Chocó”. América Negra 1: 43-65.

Maya Restrepo, Luz Adriana. 1996. “África: legados espirituales en la Nueva Granada, siglo XVII”. Historia Crítica 12: 29-42. https://doi.org/10.7440/histcrit12.1996.03 
Millán, Constanza. 2009. "Ya no llega el limbo porque la gente bailando está. Prácticas de memoria en Bojayá-Chocó”. Tesis de Maestría en Antropología Social, Universidad Nacional de Colombia, Bogotá.

Million, Dian. 2009. "Felt Theory: An Indigenous Feminist Approach to Affect and History". Wicazo Sa Review 24 (2): 53-76. https://doi.org/10.1353/wic.0.0043

Morrison, Toni. 1987. Beloved. Nueva York: Penguin Books.

Mosquera, Sergio. 2000. Visiones de la espiritualidad afrochoana. Serie Ma’ Mawu, vol. 5. Quibdó: Instituto de Investigaciones Ambientales del Pacífico.

Ochoa, Ana María. 2014. Aurality. Listening and Knowledge in Nineteenth-Century Colombia. Durham: Duke University Press.

Okot Bitek, Juliane. 2019. "Songs of Soldiers: Decolonizing Political Memory Through Poetry and Song”. Tesis de doctorado, University of British Columbia, Vancouver.

Orjuela, Camila. 2016. “Que nos dejen resollar’: así se preparó Bojayá para el perdón de las FARC”. Pacifista!, 15 de septiembre. https://pacifista.tv/notas/que-nos-dejen-resollar-asise-preparo-bojaya-para-el-perdon-de-las-farc/

-. 2017. "Ecos, resonancias y disonancias de una conmemoración”. Ponencia presentada en el Congreso Latin American Studies Association, Lima, Perú. 29 de abril-1. ${ }^{\circ}$ de mayo.

Oslender, Ulrich. 2016. The Geographies of Social Movements. Afro-Colombian Mobilization and the Aquatic Space. Durham: Duke University Press.

Ospina, Gilberto. 2004. "La fosa de Bojayá”. Revista del Instituto Nacional de Medicina Legal y Ciencias Forenses 18 (1): 52-54.

Oviedo Castrillón, Laura. 2018. “Oí, vengo de un río. Historias de mujeres pogueñas”. Revista Vive Afro. https://www.revistaviveafro.com/index.php/menu/ediciones/oi-vengo-deun-rio-historias-de-mujeres-poguenas

Quiceno, Natalia. 2016. Vivir sabroso. Luchas y movimientos afroatrateños en Bojayá, Chocó, Colombia. Bogotá: Universidad del Rosario.

Riaño-Alcalá, Pilar y Erin Baines. 2011. “Cuando el archivo está en el testigo: documentación en escenarios de inseguridad crónica”. Análisis Político 74: 49-70. https://revistas. unal.edu.co/index.php/anpol/article/view/43717

Rutherford, Danilyn. 2016. "Affect Theory and the Empirical”. Annual Review of Anthropology 45: 285-300. DOI: 10.1146/annurev-anthro-102215-095843

Stengers, Isabelle. 2013. "Introductory Notes on an Ecology of Practices". Cultural Studies Review 11 (1): 183-196. DOI: 10.5130/csr.v11i1.3459

Tobón, Alejandro. 2016. Romances del Atrato. Cantos de la vida y de la muerte. Bogotá: Instituto Caro y Cuervo.

Tobón, Alejandro, Federico Ochoa, Sara López Marín y Julián Serna Gallego. 2015. El río que baja cantando. Estudio etnomusicológico sobre romances de tradición oral del Atrato Medio. Medellín: Universidad de Antioquia.

Valencia, Leónidas. 2009. Al son que me toquen canto y bailo. Cartilla de iniciación musical. Bogotá: Ministerio de Cultura. 
Vergara-Figueroa, Aurora. 2017. Afrodescendant Resistance to Deracination in Colombia. Cham: Palgrave Macmillan.

Villa, William. 1998. "Movimiento social de comunidades negras en el Pacífico colombiano: la construcción de una noción de territorio y región”. En Los afrocolombianos. Geografía humana de Colombia, editado por Adriana Maya, 431-448. Bogotá: Instituto Colombiano de Cultura Hispánica. 